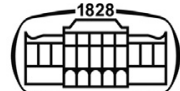

AKADÉMIAI KIADÓ

Acta Chromatographica

33 (2021) 2, 153-161

DOI:

$10.1556 / 1326.2020 .00762$

(c) 2020 The Authors

\section{ORIGINAL RESEARCH} PAPER

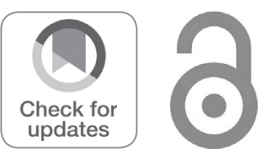

\title{
Antitumor chemical constituents of Toddalia asiatica (Linn) Lam root bark and its rational alternative medicinal parts by multivariate statistical analysis
}

\author{
CAIRONG LUO, JIE LIU, YAN LIANG, XIANGCHUN SHEN, \\ XIAOYAN ZHANG* (D) and WEI ZHOU* (B)
}

School of Pharmacy, Key Laboratory of Optimal Utilizaiton of Natural Medicine Resources, Guizhou Medical University, Guiyang, Guizhou, 550025, PR China

Received: January 15, 2020 • Accepted: April 06, 2020

Published online: June 5, 2020

\begin{abstract}
Toddalia asiatica (Linn) Lam (T. asiatica) as a traditional Miao medicine was investigated to find rational alternative medicinal parts for T. asiatica root bark and its antitumor chemical constituents by quantitative pharmacognostic microscopy, high performance liquid chromatography (HPLC) fingerprint and multivariate statistical analysis. A bivariate correlation analysis method based on microscopic characteristics and content of chemical constituents was established for the first time, there were some regular discoveries between powder microscopic characteristics and common chromatographic peaks of T. asiatica through quantitative pharmacognostic microscopy, cork cells, calcium oxalate square crystal, brown clump, starch granule and phloem fiber, as powder microscopic characteristics may be placed where the main chemical constitutes were enriched. Scores plot of principal component analysis (PCA) and dendrogram of hierarchical clustering analysis (HCA) showed that $18 \mathrm{~T}$. asiatica samples were distinguished correctly, clustered clearly into two main groups as follows: S01 S03 (root bark) and S07 S09 (stem bark) in cluster 1, S04 S06 and S10 S18 in cluster 2. Nineteen common peaks were obtained in HPLC fingerprint of T. asiatica, loadings plot of PCA indicated seven compounds played important roles in different part of samples $(\mathrm{P} 10>\mathrm{P} 08>\mathrm{P} 07>\mathrm{P} 14>\mathrm{P} 16>\mathrm{P} 17>\mathrm{P} 19)$, peaks 04, 06, $07,08,10$ were identified as hesperidin, 4-methoxycinnamic acid, toddalolactone, isopimpinlline and pimpinellin. MTT assay was used to determine the inhibitory activity of different medicinal parts of $T$. asiatica on human breast cancer MCF-7 cells, all parts of T. asiatica had different inhibitory effects on MCF-7 cell lines, root and stem barks of T. asiatica showed the best inhibitory activity. The relationship between chemical constituents and the inhibitions on MCF-7 cell had been established, significant antitumor constituents of T. asiatica were identified by correlation analysis, the order of the antitumor effect of the main compounds was P07 (toddalolactone) $>$ P16 > P06 (4-methoxycinnamic acid), P11 > P18 > P10 (pimpinellin) > P08 (isopimpinellin) $>$ P01 > P19 > P14 > P04 (hesperidin) > P17, which were antitumor chemical constituents of $T$. asiatica root bark. T. asiatica stem bark was the most rational alternative medicinal part for T. asiatica root bark.
\end{abstract}

\section{KEYWORDS}

alternative medicinal part, antitumor, chemometrics, natural medicine, Toddalia asiatica (Linn) Lam

\section{INTRODUCTION}

Corresponding authors. E-mail: drxyzhang@126.com (X. Zhang), drwzhou@126.com (W. Zhou)

\section{AKJournals}

Toddalia asiatica (Linn) Lam (T. asiatica) as a traditional Miao medicine of Chinese Materia Medica (CMM), belonging to Toddalia Juss genus, Rutaceae family was first recorded in " $Z$ hi Wu Ming Shi Tu Kao" of Qing Dynasty, it is widely distributed in Guizhou, Guangxi and other provinces in Southwest China, its root bark as a traditional medicinal part of T. asiatica, which has obvious pharmacological activities of hemostasis, anti-tumor, anti- 
inflammatory and analgesic, is widely used in the minority Miao for clinical treatment of traumatic injury, knife wound hemorrhage, tumor and rheumatic pain [1-5]. CMM as an important kind of natural medicines on the guidance of traditional Chinese medicine (TCM) theory has been used clinically for thousands of years in China, CMM have been followed up to now by their own exact pharmacological action and clinical effect. But, there is a main reason that TCM or CMM has always been questioned by western medical scholars due to complex chemical constituents and unclear pharmacological mechanisms of CMM [6], how to scientifically clarify the effective compounds of CMM has become an urgent problem to be solved with the continuous development of modern medicine.

Meanwhile, under the huge clinical demand for T. asiatica root bark and current drug market driven by actual economic interests, whole root slice and whole stem slice of $T$. asiatica are the main forms of T. asiatica instead of its traditional medicinal part - root bark. This chaotic use of CMM made it necessary for us to carry out research on rational medicinal parts of T. asiatica, and find out more suitable alternative parts of $T$. asiatica for T. asiatica root bark. In recent years, some researchers had tried to address these pratical challenges through studies on phytochemistry, LC fingerprinting and LC-MSMS analysis of T. asiatica [710], our group also had carried out a series of pharmacodynamic material basis studies on T. asiatica root bark in the previous research work, its hemostatic activity was systematically verified through animal model experiments, a lot of natural furocoumarins from T. asiatica root bark had been detected, isolated and finally identified [11-15]. However, the findings of these studies still did not pay attention to the rationality of medicinal parts of T. asiatica, as there were no comparative studies of all possible medicinal parts of $T$. asiatica, some of them such as root core of $T$. asiatica even had been used in drug market by default until now without any relevant drug quality standards and scientific research data support.

High performance liquid chromatography (HPLC) fingerprint technology as an important analytical method had got quick development in many areas such as TCMs, food and biological samples. It can be a relatively effective method to evaluate the quality of complex TCMs as a whole [16-18]. In order to further explore the differences of all medicinal parts of $T$. asiatica, the obtained data were statistically processed by multivariate statistical analysis including bivariate analysis, hierarchical clustering analysis (HCA) and principal component analysis (PCA). Multivariate statistical analysis was used to evaluate the intrinsic quality of T. asiatica and to identify the chemical constituents that are most responsible for quality control of different medicinal parts of $T$. asiatica $[19,20]$. HPLC fingerprint profiling combined with quantitative pharmacognostic microscopy, pharmacological activity and multivariate statistical analysis was a novel strategy for assessing different medicinal parts of $T$. asiatica in this study. Our research group had conducted deep and systematic research on different parts of T. asiatica and their antitumor effects for the first time, so as to solve current chaos of T. asiatica, clarify on its antitumor material basis and to scientifically confirm the rational alternative medicinal part of T. asiatica.

\section{MATERIALS AND METHODS}

\section{Plant materials}

Eighteen batches of different medicinal parts of T. asiatica including root bark, root core, stem bark, stem core, nearleaf stem and leaf collected from Qixing mountain area, Duyun, Guizhou in the southwest of China were investigated (Table 1). T. asiatica samples were ground into powder of the homogenous 24 mesh before the experiment. All samples had been identified by Professor Zhiyou Guo, Qiannan Normal University for Nationalities, and the specimens were

Table 1. The origins of different medicinal parts of Toddalia asiatica

\begin{tabular}{|c|c|c|c|}
\hline $\begin{array}{l}\text { Sample } \\
\text { no. }\end{array}$ & $\begin{array}{c}\text { Medicinal parts of } \\
\text { T. asiatica }\end{array}$ & Origins & $\begin{array}{l}\text { Collecting } \\
\text { time }\end{array}$ \\
\hline 01 & Root bark & $\begin{array}{l}\text { Duyun, } \\
\text { Guizhou }\end{array}$ & July, 2018 \\
\hline 02 & Root bark & $\begin{array}{l}\text { Duyun, } \\
\text { Guizhou }\end{array}$ & July, 2018 \\
\hline 03 & Root bark & $\begin{array}{l}\text { Duyun, } \\
\text { Guizhou }\end{array}$ & July, 2018 \\
\hline 04 & Root core & $\begin{array}{l}\text { Duyun, } \\
\text { Guizhou }\end{array}$ & July, 2018 \\
\hline 05 & Root core & $\begin{array}{l}\text { Duyun, } \\
\text { Guizhou }\end{array}$ & July, 2018 \\
\hline 06 & Root core & $\begin{array}{l}\text { Duyun, } \\
\text { Guizhou }\end{array}$ & July, 2018 \\
\hline 07 & Stem bark & $\begin{array}{l}\text { Duyun, } \\
\text { Guizhou }\end{array}$ & Sept, 2018 \\
\hline 08 & Stem bark & $\begin{array}{l}\text { Duyun, } \\
\text { Guizhou }\end{array}$ & Sept, 2018 \\
\hline 09 & Stem bark & $\begin{array}{l}\text { Duyun, } \\
\text { Guizhou }\end{array}$ & Sept, 2018 \\
\hline 10 & Stem core & $\begin{array}{l}\text { Duyun, } \\
\text { Guizhou }\end{array}$ & Sept, 2018 \\
\hline 11 & Stem core & $\begin{array}{l}\text { Duyun, } \\
\text { Guizhou }\end{array}$ & Sept, 2018 \\
\hline 12 & Stem core & $\begin{array}{l}\text { Duyun, } \\
\text { Guizhou }\end{array}$ & Sept, 2018 \\
\hline 13 & Near-leaf stem & $\begin{array}{l}\text { Duyun, } \\
\text { Guizhou }\end{array}$ & $\begin{array}{l}\text { August, } \\
2018\end{array}$ \\
\hline 14 & Near-leaf stem & $\begin{array}{l}\text { Duyun, } \\
\text { Guizhou }\end{array}$ & $\begin{array}{l}\text { August, } \\
2018\end{array}$ \\
\hline 15 & Near-leaf stem & $\begin{array}{l}\text { Duyun, } \\
\text { Guizhou }\end{array}$ & $\begin{array}{l}\text { August, } \\
2018\end{array}$ \\
\hline 16 & Leaf & $\begin{array}{l}\text { Duyun, } \\
\text { Guizhou }\end{array}$ & $\begin{array}{l}\text { August, } \\
2018\end{array}$ \\
\hline 17 & Leaf & $\begin{array}{l}\text { Duyun, } \\
\text { Guizhou }\end{array}$ & $\begin{array}{l}\text { August, } \\
2018\end{array}$ \\
\hline 18 & Leaf & $\begin{array}{l}\text { Duyun, } \\
\text { Guizhou }\end{array}$ & $\begin{array}{l}\text { August, } \\
2018\end{array}$ \\
\hline
\end{tabular}


deposited in Herbarium of Chinese Materia Medica and Ethnomedicines, School of Pharmacy, Guizhou Medical University.

\section{Cells, chemicals and reagents}

MCF-7 cells were purchased from China Center for Type Culture Collection (CCTCC) of Wuhan University, less than 10 generations of cell passage. Eleven authentic compounds were used in the present study, namely, hesperidin (P04), 4-methoxycinnamic acid (P06), toddalolactone (P07), isopimpinellin (P08), pimpinellin (P10), methyl trans-4-hydroxycinnamate (P20), avenalumic acid methyl ester (P21), ferulic acid methyl ester (P22), bergapten (P23), moellendorffiline (P24) and phellopterin (P25). These were isolated and prepared from T. asiatica, identified by our research group in our previous research, and their purities in HPLC are more than 98\%. DMEM culture medium (Lot No 8118403, GIBCO), Fetal bovine serum (Lot No 1P1701, SeraPro S601-500), Trypsin digestive fluid (Lot No 1951208, GIBCO), Phosphate buffer saline (Lot No 1015M022, Solarbio), MTT (Lot No 829Z0513, Solarbio), DMSO (Lot No 1213C0222, Solarbio), 75\% medical alcohol (Lot No 190414, Guizhou Kangtai Lijian), Methanol (HPLC pure, Shanghai Sinopharm Chemical), Glycerol (Shanghai Sinopharm Chemical), Chloral hydrate (Shanghai Macklin Biochemical), Pure water (Watsons), 96-well Cell culture plate (Lot No 180809-078, Guangzhou Jet Bio-Filtration) were purchased for the analysis.
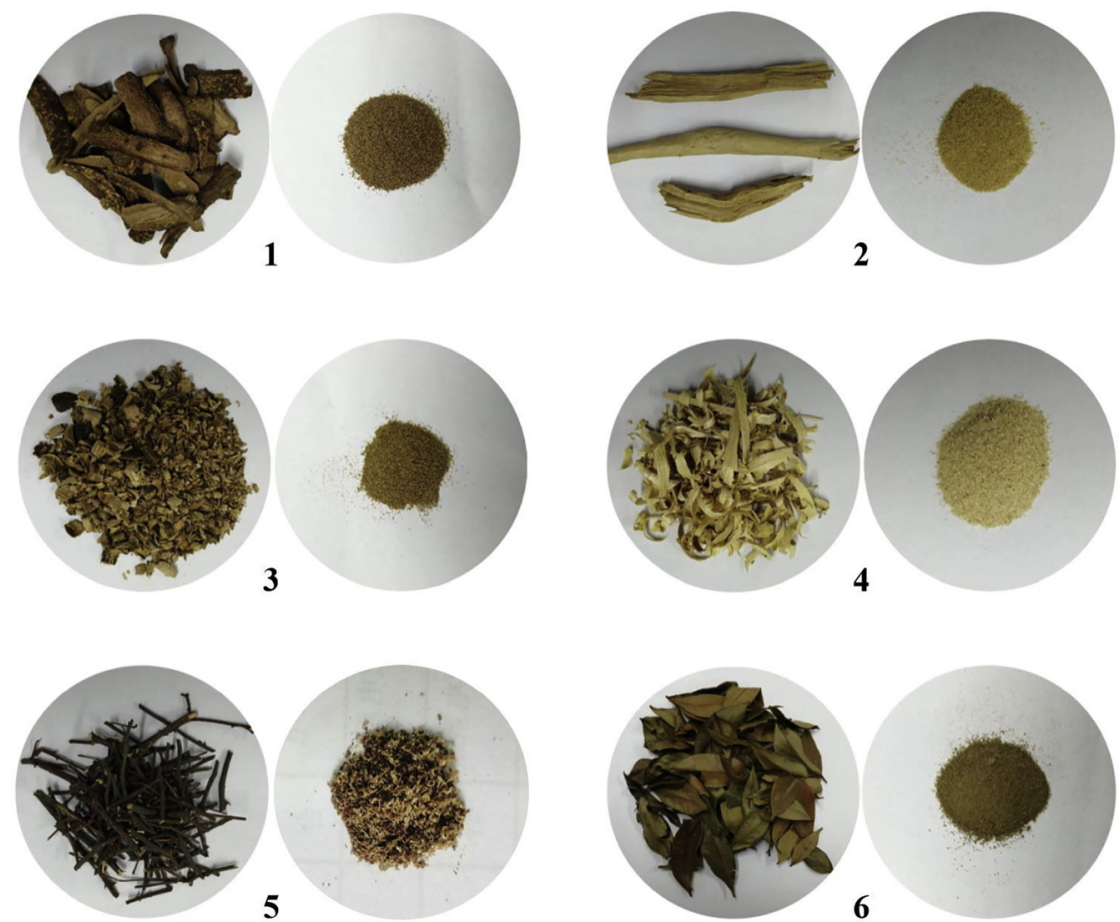

\section{Instruments}

Agilent 1260 infinity HPLC-DAD system (Agilent), R-1001VN rotary evaporator (Zhengzhou Greatwall Scientific), SHB-III water circulating multi-purpose vacuum pump (Zhengzhou Greatwall Scientific), SB-5200D ultrasonic cleaning machine (Ningbo Scientz), TS100 Inverted Microscope (Nikon), Epoch microplate reader (Biotek), Thermo Forma 3131 carbon dioxide cell incubator (Thermo), TDL-40B centrifuge (Changzhou Langyue), HH-501 thermostatic water bath (Changzhou Langyue) and HK-UP-20 Ultra-pure water preparation system (Hefei Hongke) were used for the analysis.

\section{Sample preparation}

About $6.0 \mathrm{~g}$ of root bark, root core, stem bark, stem core, near-leaf stem or leaf of T. asiatica was soaked separately in methanol for $24 \mathrm{~h}$ at a solid-liquid ratio of 1:50 (g:mL), extracted three times by reflux method for $2 \mathrm{~h}$ each time in a $65^{\circ} \mathrm{C}$-constant temperature water bath $[9,11,21]$. Six extracts from different parts of T. asiatica were finally prepared. Each accurately-weighed extract of $T$. asiatica was dissolved in methanol and fixed in their respective $25-\mathrm{mL}$ volumetric flasks. All sample solutions were filtered through $0.22-\mu \mathrm{m}$ lipophilic microporous filters before LC analysis.

The standard reference solutions were prepared by adding an accurately-weighed amount of above-mentioned eleven natural compounds to a $10-\mathrm{mL}$ volumetric flask, respectively, dissolved with methanol to make $100.0 \mu \mathrm{g} / \mathrm{mL}$ of the final concentrations as the stock solutions prepared for analysis.
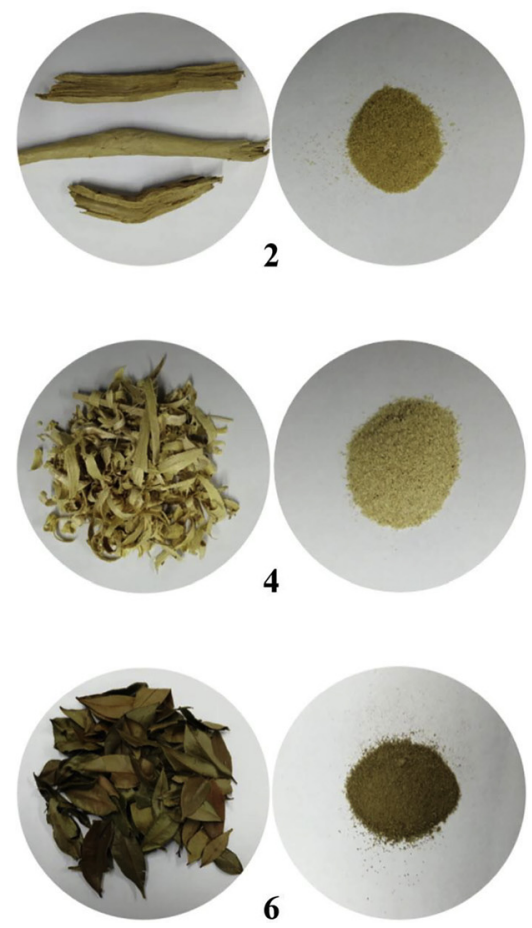

Fig. 1. The appearance of differental parts of Toddalia asiatica and their powders. 1: Root bark of T. asiatica and its powder. 2: Root core of T. asiatica and its powder. 3: Stem bark of T. asiatica and its powder. 4: Stem core of T. asiatica and its powder. 5: Near-leaf stem of T. asiatica and its flake. 6: Leaf of T. asiatica and its powder 


\section{Microscopical character analysis of pharmacognostical powder}

The root bark, root core, stem bark, stem core, near-leaf stem and leaf of T. asiatica were pulverized by a pulverizer, sieved by a 24 -mesh sieve to obtain the medicinal material powders to be tested (Fig. 1). The right amount of the powder from different parts of $T$. asiatica was taken out separately, placed on a glass slide of $7.5 \mathrm{~cm} \times 2.5 \mathrm{~cm}$ and dripped with $2 \sim 3$ drops of chloral hydrate-glycerol test solution for further 2-3 s of heat treatment under the flame of an alcoholic lamp, then each sample on the glass slide was covered with a cover glass without generating bubbles. All these glass slides with sample powders were observed under an inverted microscope to do microscopical character analysis of pharmacognostical powder.

\section{Chromatographic condition}

Chromatographic separation was performed on a Diamonsil C18 column $(250 \mathrm{~mm} \times 4.6 \mathrm{~mm}, 5 \mu \mathrm{m})$ in a HPLC-DAD system (Agilent), the mobile phase was methanol (A)-water (B) with gradient elution of $0-10 \mathrm{~min} \mathrm{~A}: \mathrm{B}(5: 95) \rightarrow(25: 75)$, $10 \sim 50$ min $\mathrm{A}: \mathrm{B}(25: 75) \rightarrow(50: 50), 50 \sim 80 \min \mathrm{A}: \mathrm{B}(50: 50)$ $\rightarrow(80: 20), 80 \sim 95 \mathrm{~min} \mathrm{~A}: \mathrm{B}(80: 20) \rightarrow(90: 10)$ and $95-100$ $\min \mathrm{A}: \mathrm{B}(90: 10) \rightarrow(90: 10)[9,10]$. The flow rate was $1.0 \mathrm{~mL} /$ min, detection wavelength was $230 \mathrm{~nm}$, column temperature was maintained at $25^{\circ} \mathrm{C}$ and the injection volume was 20.0 $\mu \mathrm{L}$ by automatic sampling system at $4{ }^{\circ} \mathrm{C}$.

\section{Evaluation of anti-tumor activities of different parts of T. asiatica}

MCF-7 cells in logarithmic growth stage were selected and inoculated into 96-well plates at a cell density of $1 \times 10^{4} /$ well with $100.0 \mu \mathrm{L}$ DMEM culture medium, six duplicates in each group 12.5 200.0 $\mu \mathrm{g} / \mathrm{mL}$ extracts of six medicinal parts of T. asiatica (root bark, root core, stem bark, stem core, near-leaf stem and leaf) in 0.1\%-DMSO DMEM culture medium were added respectively and incubated at $37^{\circ} \mathrm{C}, 5 \%$ $\mathrm{CO}_{2}$ for $24 \mathrm{~h}$ in the dark, while $0.1 \%$-DMSO DMEM culture medium without drug treatment was set up as Blank control group. Then, $15 \mu \mathrm{L}$ of $5 \%$ MTT solution was added to each well in the dark. These cells were continuously incubated at $37{ }^{\circ} \mathrm{C}, 5 \% \mathrm{CO}_{2}$ for $4 \mathrm{~h}$, the supernatant was discarded, 150 $\mu \mathrm{L}$ DMSO was added to each well and shaken for $10 \mathrm{~min}$. Subsequently, the optical density (OD) of each well at 490 nm was determined by a microplate reader (Bio-Rad Laboratories, Inc.), the inhibitory rate (\%) was finally calculated by the following formula:

$$
\text { Inhibitory rate }(\%)=\frac{\mathrm{OD}_{\text {Blank }}-\mathrm{OD}_{\text {Sample }}}{\mathrm{OD}_{\text {Blank }}} \times 100 \%
$$

\section{Correlation analysis}

Quantitative pharmacognostic microscopy and multivariate statistical analysis of antitumor chemical constituents of $T$. asiatica need to be analyzed by means of correlation analysis method, which contained bivariate analysis, HCA and PCA. Bivariate analysis and HCA were performed by SPSS 22.0 (SPSS Inc), PCA was carried out by SIMCA 14.1 Software (Umetric, Sweden).

\section{RESULTS AND DISCUSSION}

\section{Pharmacognostical powder analysis}

Microscopic characteristics of powders of different medicinal parts of T. asiatica are: 1) powder of the root bark was brown, the powder microscopic characteristics were the most abundant, there were much more brown cork cells, calcium oxalate square crystals, brown clumps and reticulate vessels. Xylem fibers, non-glandular hairs, oil cells, starch granules and phloem fibers could also be characterized in the root bark; 2) powder of the root core was yellowish green, its microscopic characteristics contained yellowish brown cork cells and reticulate vessels, no calcium oxalate square crystals and stone cells were found here; 3) T. asiatica stem bark was brown, more cork cells, calcium oxalate square crystals, brown clumps and starch granules were its main microscopic powder characteristics, which were similar to T. asiatica root bark; 4) T. asiatica stem core was brown yellow, there were many wood fibers containing calcium oxalate square crystals in the powder, cork cells and reticulate vessels were also common herein; 5) the near-leaf stem was brown, it had wood fibers, cork cells, non-glandular hairs and reticulate vessels; 6) the leaf was light green in color, brown oil cells, non-glandular hairs, vessels, parenchyma cells and wood fibers were its main powder microscopic characteristics (Fig. 2).

In our opinion, the bioactive chemical constitutes of $T$. asiatica were definitely from this TCM, which showed us its own powder microscopic characteristics in the field of view of a microscope, and this prompted us to try to build correlation between powder microscopic characteristics of $T$. asiatica and 19 common chromatographic peaks through quantitative pharmacognostic microscopy. Correlation analysis method helped us to calculate their correlation coefficents, and the final data was listed in Table 2. Cork cells, calcium oxalate square crystal, brown clump, starch granule and phloem fiber obtained relatively high frequency of occurrence with common peaks $(01 \sim 19)$ from these results, these microscopic characteristics may be placed where the main chemical constitutes were concentrated and enriched, it can guide us to more purposefully extract and purify the target natural compounds. For example, phloem fiber had rich compounds of P06 $(0.805, P<0.01)$, P11 (0.539, $P<0.05)$ and P18 (0.787, $P<0.01)$.

\section{Chromatographic fingerprint analysis}

The chromatographic fingerprints of root bark, root core, stem bark, stem core, near-leaf stem and leaf of T. asiatica had been established, a total of 19 common chromatographic peaks $(01 \sim 19)$ in different medicinal parts of $T$. asiatica were confirmed, in Fig. 3, showing large peak areas 


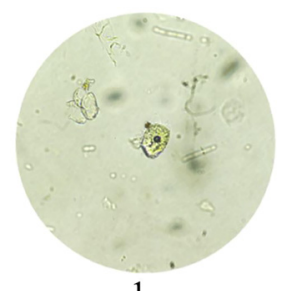

1

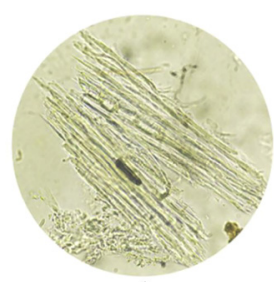

4
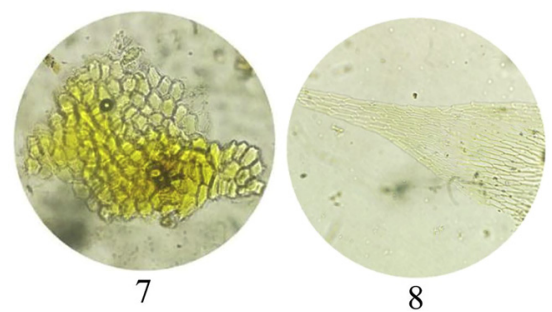

8

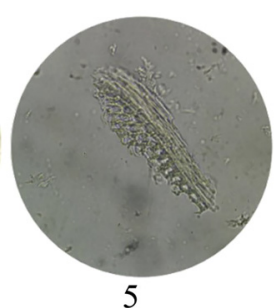

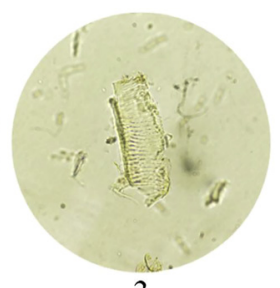

3

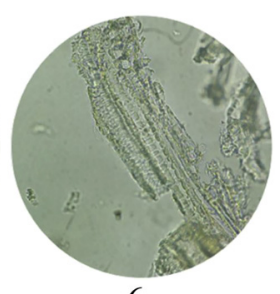

6

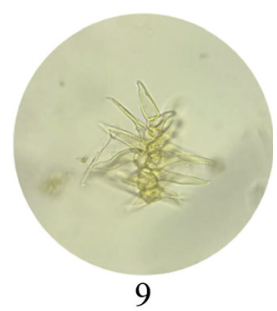

Fig. 2. Microscopic characteristics of fine powders of different parts of Toddalia asiatica $(10 \times 40)$. 1: Stone cells. 2: Calcium oxalate square crystals. 3: Reticulate vessels. 4: Wood fibers. 5: Fiber containing crystals. 6: Catheters. 7: Cork cells. 8: Parenchyma cells. 9: Non-glandular hairs and good separation from adjacent peaks. The total peak areas of 19 common peaks were more than $90 \%$ of the total peak areas. By comparing with the chromatographic peaks of our eleven reference substances, the five common chromatographic peaks $04,06,07,08$ and 10 of T. asiatica were determined to be hesperidin, 4-methoxycinnamic acid, toddalolactone, isopimpinlline and pimpinellin, respectively.

The LC fingerprints were matched automatically by use of the Similarity Evaluation System for Chromatographic Fingerprint of TCM (Version 2004), similarities of LC fingerprints of samples no. 1 18 of T. asiatica were calculated by the cosine value method of vectorial angle, and the results were detailed below: $0.9507-0.9765$ of samples no. 1-3, $0.8306 \sim 0.8570$ of samples no. $4 \sim 6,0.9824 \sim 0.9881$ of samples no. 7 9, $0.8207 \sim 0.8940$ of samples no. 10 12, $0.5571 \sim 0.5667$ of samples no. $13 \sim 15$ and $0.1328 \sim 0.1366$ of samples no. 16-18. The degree of chromatographic fingerprint similarity between $T$. asiatica root bark and T. asiatica stem bark was much higher than that of other parts. HCA was used in our study to find relatively homogeneous clusters of all six different medicinal parts of $T$. asiatica based on the peak areas of the 19 common peaks as the measured characteristics, and the results were shown in Fig. 4D, it was clear that the six parts of T. asiatica were able to be classified into two broad categories. Samples no. 1 3 of T. asiatica root bark and samples no. 7 9 of T. asiatica stem bark were in the first category, and the other samples of T. asiatica were in the second category, which was further classified into two subclusters: samples no. $4 \sim 6$ of $T$. asiatica root

Table 2. Correlation coefficents between nineteen common chromatographic peaks and powder microscopic characteristics of different parts of Toddalia asiatica

\begin{tabular}{|c|c|c|c|c|c|c|c|c|c|c|c|}
\hline & $\begin{array}{l}\text { Cork } \\
\text { cells }\end{array}$ & $\begin{array}{l}\text { Xylem } \\
\text { fiber }\end{array}$ & $\begin{array}{l}\text { Non- } \\
\text { glandular } \\
\text { hair }\end{array}$ & $\begin{array}{c}\text { Calcium } \\
\text { oxalate } \\
\text { square } \\
\text { crystal }\end{array}$ & Vessels & Oil cells & $\begin{array}{c}\text { Parenchyma } \\
\text { cells }\end{array}$ & $\begin{array}{l}\text { Brown } \\
\text { clump }\end{array}$ & $\begin{array}{l}\text { Stone } \\
\text { cells }\end{array}$ & $\begin{array}{l}\text { Starch } \\
\text { granule }\end{array}$ & $\begin{array}{l}\text { Phloem } \\
\text { fiber }\end{array}$ \\
\hline P01 & $0.685^{* *}$ & $-0.741^{* *}$ & $-0.628^{*}$ & $0.552^{*}$ & $-0.823^{* *}$ & $-0.715^{\star *}$ & -0.400 & $0.772^{* *}$ & -0.218 & 0.455 & $0.879^{* *}$ \\
\hline P02 & $-0.294^{* *}$ & $0.882^{* *}$ & $0.906^{* *}$ & -0.320 & $0.659^{* *}$ & $0.898^{* *}$ & $0.834^{* *}$ & -0.325 & $0.725^{* *}$ & 0.211 & -0.514 \\
\hline P03 & -0.266 & $0.595^{*}$ & $0.815^{* *}$ & 0.238 & 0.275 & $0.688^{* *}$ & $0.783^{* *}$ & -0.045 & $0.724^{* *}$ & 0.468 & -0.538 \\
\hline P04 & $0.748^{* *}$ & $-0.661^{* *}$ & -0.400 & $0.951^{* *}$ & $-0.727^{* *}$ & $-0.547^{*}$ & -0.336 & 0.504 & -0.086 & 0.424 & 0.312 \\
\hline P05 & -0.003 & 0.183 & 0.415 & $0.579^{*}$ & -0.114 & 0.293 & 0.455 & 0.302 & $0.710^{\star *}$ & $0.772^{* *}$ & 0.180 \\
\hline P06 & -0.115 & -0.161 & -0.274 & 0.073 & -0.065 & -0.175 & -0.278 & 0.095 & 0.158 & 0.236 & $0.805^{* *}$ \\
\hline P07 & $0.563^{*}$ & $-0.691^{* *}$ & $-0.592^{*}$ & $0.683^{* *}$ & $-0.661^{* *}$ & $-0.636^{\star}$ & -0.508 & 0.501 & -0.112 & 0.393 & $0.799^{* *}$ \\
\hline P08 & 0.425 & -0.487 & -0.341 & $0.726^{* *}$ & $-0.577^{*}$ & -0.411 & -0.243 & $0.546^{*}$ & 0.190 & $0.631^{*}$ & $0.809^{* x}$ \\
\hline P09 & $-0.814^{* *}$ & $0.981^{* *}$ & $0.971^{* *}$ & -0.417 & $0.766^{* *}$ & $0.987^{* *}$ & $0.882^{\star *}$ & -0.397 & $0.783^{* *}$ & 0.192 & $-0.520^{*}$ \\
\hline P10 & 0.435 & -0.507 & -0.367 & $0.718^{\star *}$ & $-0.586^{\star}$ & -0.433 & -0.268 & $0.547^{\star}$ & 0.163 & $0.613^{*}$ & $0.821^{\star \star}$ \\
\hline P11 & -0.296 & 0.140 & 0.087 & 0.076 & 0.125 & 0.153 & 0.054 & 0.006 & 0.444 & 0.360 & $0.539^{*}$ \\
\hline $\mathrm{P} 12$ & 0.486 & -0.287 & -0.012 & $0.731^{* *}$ & $-0.536^{*}$ & -0.185 & 0.119 & $0.559^{*}$ & 0.228 & $0.621^{*}$ & 0.229 \\
\hline $\mathrm{P} 13$ & $-0.796^{* *}$ & $0.840^{* *}$ & $0.821^{* *}$ & -0.206 & $0.654^{* *}$ & $0.864^{* *}$ & $0.724^{* *}$ & -0.297 & $0.918^{* *}$ & 0.413 & 0.073 \\
\hline P14 & $0.634^{*}$ & $-0.563^{*}$ & -0.313 & $0.882^{* *}$ & $-0.757^{* *}$ & -0.463 & -0.146 & $0.735^{* *}$ & 0.158 & $0.735^{* *}$ & $0.689^{* x}$ \\
\hline P15 & $0.751^{* *}$ & -0.445 & -0.085 & $0.862^{* *}$ & $-0.759^{* *}$ & -0.329 & 0.118 & $0.752^{* *}$ & 0.083 & $0.648^{* *}$ & 0.132 \\
\hline P16 & 0.244 & -0.402 & -0.349 & $0.530^{*}$ & -0.414 & -0.354 & -0.293 & 0.392 & 0.184 & 0.509 & $0.862^{* *}$ \\
\hline P17 & $0.611^{*}$ & -0.473 & -0.193 & $0.874^{* *}$ & $-0.707^{* *}$ & -0.364 & -0.031 & $0.703^{* *}$ & 0.201 & $0.732^{* *}$ & $0.516^{*}$ \\
\hline P18 & -0.120 & -0.144 & -0.236 & 0.145 & -0.057 & -0.144 & -0.259 & 0.079 & 0.218 & 0.280 & $0.787^{* *}$ \\
\hline P19 & 0.011 & 0.065 & 0.174 & 0.246 & -0.160 & 0.105 & 0.289 & 0.366 & 0.416 & $0.563^{*}$ & 0.375 \\
\hline
\end{tabular}

Notes: ${ }^{\star} P<0.05$ statistically significant correlation, ${ }^{* *} P<0.01$ statistically very significant correlation.

Bold values are chromatographic peaks. 

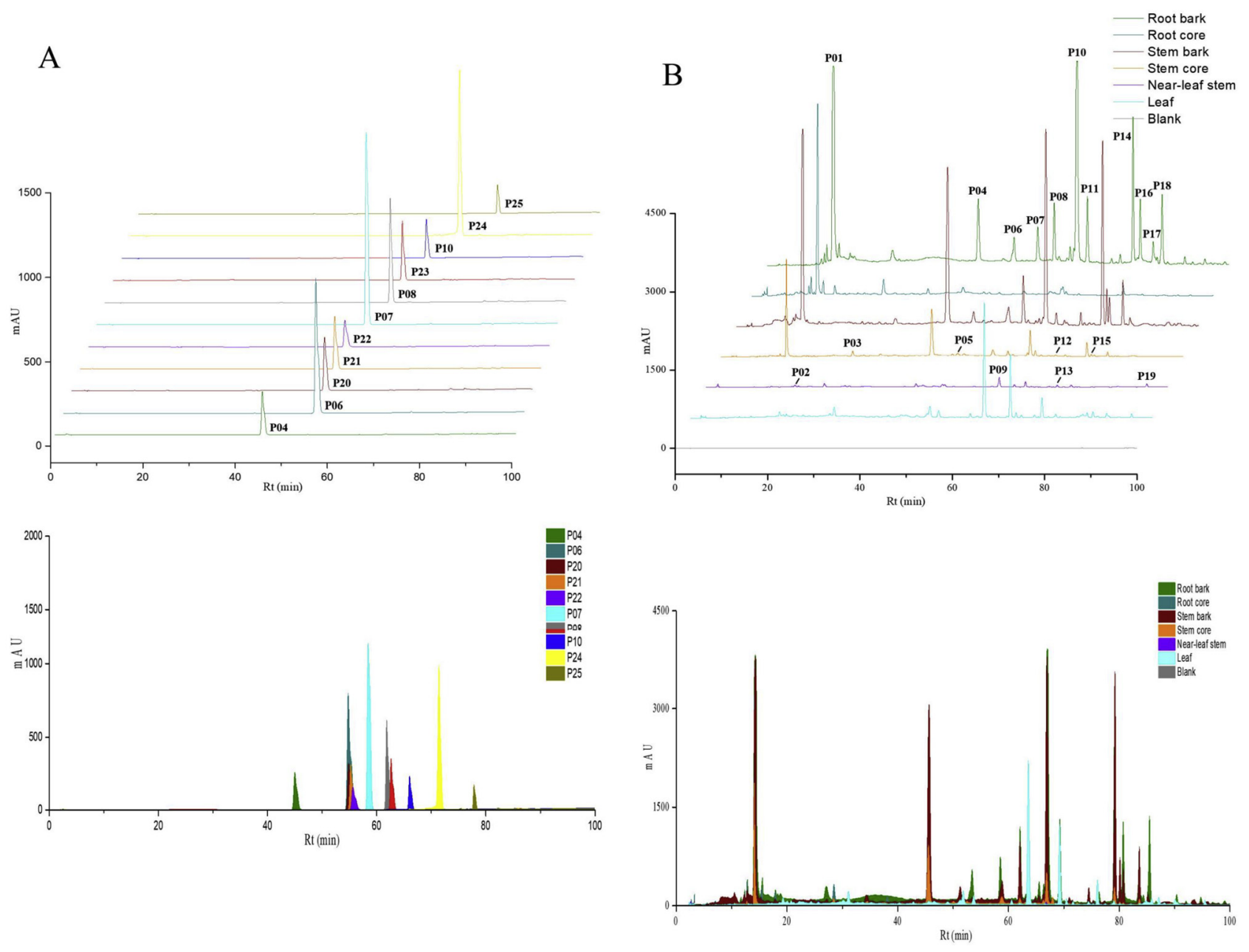

Fig. 3. HPLC-UV chromatograms of standard references (A) and different medicinal parts of Toddalia asiatica (B)

core, samples no. 10 12 of T. asiatica stem core and samples no. $13 \sim 15$ of T. asiatica near-leaf stem as one subcluster, and samples no. $16 \sim 18$ of $T$. asiatica leaf as the other subcluster.

PCA involves a mathematical procedure that transforms a number of possibly correlated variables into a number of uncorrelated variables called principal components. It is the unsupervised multivariate data analysis approach, and appropriate when a function of many attributes is involved in differences between samples. PCA was able to provide the accurate component that played the most important role in the discrimination of the different medicinal parts of $T$. asiatica, PCA on 19 common peaks of LC fingerprints of $T$. asiatica samples was obtained to find the possible chemical markers for the discrimination of different medicinal parts of $T$. asiatica. The 3D matrix was composed of 18 observations and 19 variables, which indicated samples and the various markers measured by HPLC, respectively. Based on eigenvalues higher than 1 , the first $\left(\lambda_{1}=10.3\right)$, the second $\left(\lambda_{2}=3.32\right)$ and the third $\left(\lambda_{3}=2.84\right)$ uncorrelated principal components accounted for $57.3 \%, 18.5 \%$ and $15.8 \%$ contribution rate of variance, respectively, and cumulative contribution rate of these three principal components had reached 91.5\% (Fig. 4B). Eighteen batches of samples were divided into four groups in 3D score plot: Group 1 S01 S03; Group 2 - S07 S09; Group 3 - S04 S06, S10 12 and S13 15; and Group $4-$ S16 S18. Group 1 and Group 2 would be merged into one group in $2 \mathrm{D}$ score plot (Fig. 4A). The three principal components were assigned to evaluate the similarities and differences of the samples. The loading plot (Fig. 4C) indicated that seven compounds played important roles in the samples, $\mathrm{P} 10>\mathrm{P} 08>\mathrm{P} 07>\mathrm{P} 14>\mathrm{P} 16$ $>\mathrm{P} 17>\mathrm{P} 19$. In particular, $\mathrm{P} 10, \mathrm{P} 8$ and $\mathrm{P} 7$ showed more influence on the discrimination of different medicinal parts of T. asiatica than other peaks, which might be the chemical markers for quality control of T. asiatica. Peaks 10, 08 and 07 were also confirmed to natural compounds pimpinellin, isopimpinlline and toddalolactone.

\section{Antitumor activities of different medicinal parts of $T$. asiatica}

Antitumor activities of different medicinal parts (root bark, root core, stem bark, stem core, near-leaf stem and leaf) of $T$. asiatica were considered to deeply evaluate their differences 

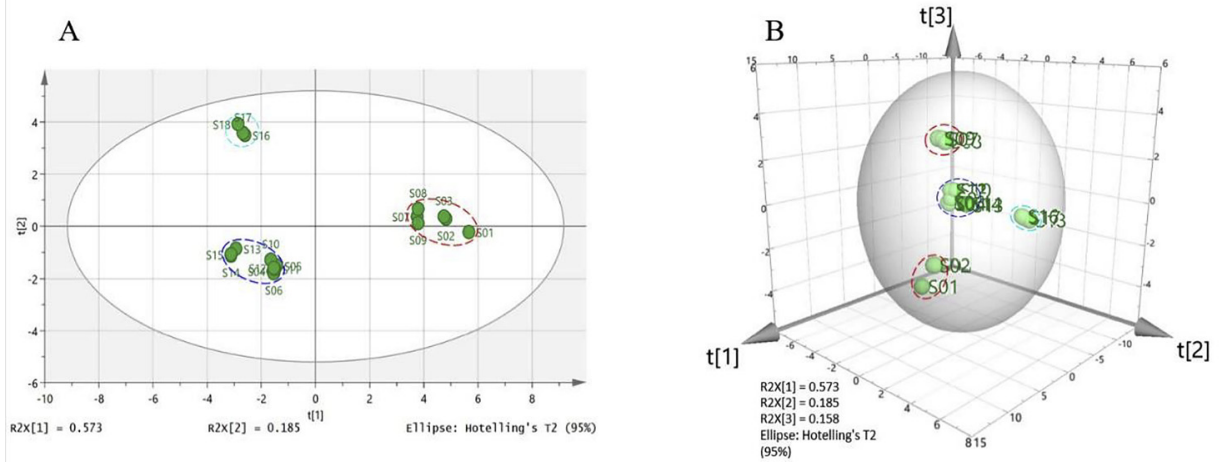

$\mathrm{C}$

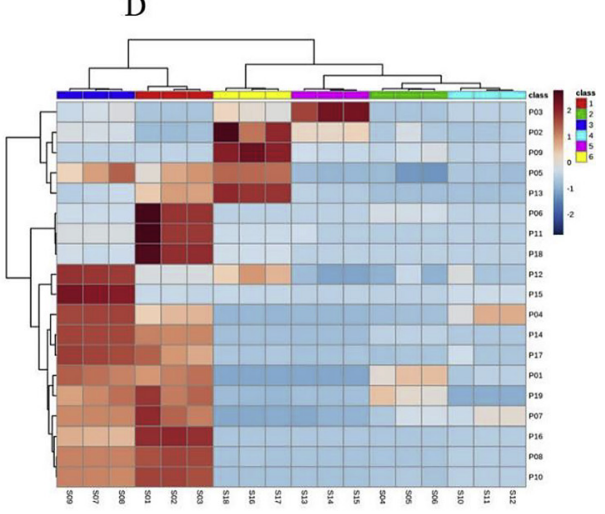

Fig. 4. Scores plot of PCA (A, B), loadings plot of PCA (C), dendrogram and heatmap of HCA (D) of different parts of Toddalia asiatica. Red color represents to higher concentration, while blue color corresponds to lower concentration. S1, S2, S3: Root bark of T. asiatica. S4, S5, S6: Root core of T. asiatica. S7, S8, S9: Stem bark of T. asiatica. S10, S11, S12: Stem core of T. asiatica. S13, S14, S15: Near-leaf stem of T. asiatica. S16, S17, S18: Leaf of T. asiatica. P: Liquid chromatography peak

through classical MTT experimental method. Anti-tumor mean inhibitory rate (\%) of $100.0 \mu \mathrm{g} / \mathrm{mL}$ different medicinal parts of T. asiatica on human breast cancer MCF-7 cells showed clear pharmacodynamic action law: root bark $(58.23 \%)$, stem bark $(48.03 \%)>$ root core $(27.01 \%)$, stem core $(33.01 \%)>$ near-leaf stem $(7.69 \%)$, leaf $(6.64 \%)$, and the inhibition rate showed a significant upward trend with the increase of test sample concentration of treated MCF-7 cells. T. asiatica root bark and root core can significantly inhibit the proliferation of MCF-7 breast cancer cells $(P<$ 0.01) than other parts (Fig. 5). Through bivariate analysis, correlation between 19 characteristic peaks and antitumor inhibition rate of different medicinal parts of $T$. asiatica

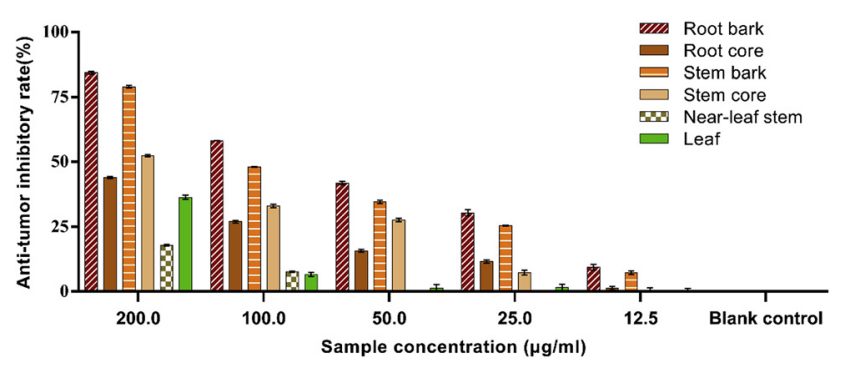

Fig. 5. The inhibitory effect of extracts from different parts of the Toddalia asiatica on MCF-7 cells had been established, and reflected in the form of correlation coefficients of peaks $01 \sim 19\left({ }^{\star} P<0.05,{ }^{\star *} P<0.01\right)$ : $0.739^{\star \star}(\mathrm{P} 01),-0.719^{\star \star}(\mathrm{P} 02),-0.673^{\star \star}(\mathrm{P} 03), 0.555^{\star}(\mathrm{P} 04)$, 0.166(P05), $0.783^{\star \star}(\mathrm{P} 06), \quad 0.854^{\star *}(\mathrm{P} 07), \quad 0.751^{\star \star}(\mathrm{P} 08)$, $-0.537^{\star \star}(\mathrm{P} 09), \quad 0.769^{\star \star}(\mathrm{P} 10), \quad 0.783^{\star \star}(\mathrm{P} 11), 0.337(\mathrm{P} 12)$, $-0.096(\mathrm{P} 13), \quad 0.600^{*}(\mathrm{P} 14), \quad 0.054(\mathrm{P} 15), \quad 0.813^{* *}(\mathrm{P} 16)$, $0.550^{\star}(\mathrm{P} 17), 0.775^{\star \star}(\mathrm{P} 18), 0.717^{\star \star}(\mathrm{P} 19)$. The above results of statistical analysissuggested that some compounds in $T$. asiatica showed strong antitumor activities, their orders were P07 (toddalolactone) > P16 > P06 (4-methoxycinnamic acid), P11 > P18 > P10 (pimpinellin) > P08 (isopimpinellin) $>$ P01 > P19 > P14 > P04 (hesperidin) $>$ P17 in turn.

\section{CONCLUSION}

A novel strategy integrating quantitative pharmacognostic microscopy, pharmacological activity and multivariate statistical analysis was successfully set up herein for assessing different medicinal parts of $T$. asiatica, an HPLC-UV method was established to evaluate the quality of different medicinal parts of $T$. asiatica, antitumor chemical constituents of $T$. asiatica and rational alternative parts for the root bark by quantitative 
pharmacognostic microscopy and multivariate statistical analysis. The powder microscopic characteristics of different medicinal parts of $T$. asiatica had gone through systematic analysis and comparison. Cork cells, calcium oxalate square crystal, brown clump, reticulate vessels, oil cells, stone cells and xylem fibers were the main powder microscopic characteristics of $T$. asiatica. The main natural compounds of T. asiatica were concentrated in cork cells, calcium oxalate square crystals, brown clumps, starch granules and phloem fibers. The results of multivariate statistical analysis illustrated that different medicinal parts of T. asiatica could be classified, and pimpinellin, isopimpinlline and toddalolactone were highlighted as potential chemical markers for discrimination of different medicinal parts of T. asiatica and quality control of $T$. asiatica. This study fills the blank space for the research work of rational medicinal parts of T. asiatica, and is helpful in establishing a scientific and rational method for explaining T. asiatica stem bark as a rational alternative medicinal part for $T$. asiatica root bark and solving current chaos of T. asiatica in the drug market.

\section{CONFLICTS OF INTEREST}

The authors declare that there is no conflict of interest.

\section{ACKNOWLEDGMENTS}

This work was financially supported by National Natural Science Foundation of China (81360681), Guizhou Provincial Natural Science Foundation (2020-1Y404), Open Undergraduate Experimental Project of Guizhou Medical University (2018-8), Teaching Engineering Project of Guizhou Medical University (WK2018-8), and Reform Project of Undergraduate Teaching Content and Course System of Guizhou Medical University (2019-60).

\section{ABBREVATIONS}

$\begin{array}{ll}\text { CMM } & \text { Chinese materia medica } \\ \text { HCA } & \text { hierarchical clustering analysis } \\ \text { HPLC } & \text { high performance liquid chromatography } \\ \text { MTT } & \text { methyl thiazolyl tetrazolium } \\ \text { PCA } & \text { principal component analysis } \\ \text { TCM } & \text { traditional Chinese medicine }\end{array}$

\section{REFERENCES}

1. Iwasaki, H.; Okabe, T.; Takara, K.; Toda, T.; Shimatani, M.; Oku, H. Tumor-selective cytotoxicity of benzo[c]phenanthridine derivatives from Toddalia asiatica Lam. Cancer Chemoth. Pharm. 2010, 65(4), 719-26.
2. Li, X; Qiu, Z. D.; Jin, Q. H.; Chen, G. L.; Guo, M. Q. Cell cycle arrest and apoptosis in HT-29 cells induced by dichloromethane fraction from Toddalia asiatica (L.) Lam. Front. Pharmacol. 2018, 9, 629.

3. Zhu, Y. Z.; Pan, Y. Y.; Zhang, G. B.; Wu, Y. C.; Zhong, W. C.; Chu, C. X.; Qian, Y.; Zhu, G. F. Chelerythrine inhibits human hepatocellular carcinoma metastasis in vitro. Biol. Pharm. Bull. 2018, 41(1), 36-46.

4. Lu, Y.; Zhu, Y. Z.; Cuo, C. X.; Han, C.; Zhu, G. F.; Pan, Y. Y. Analgesic effect of Toddalia Asiatica's extract and its peripheral analgesic mechanism. Shanghai J. Tradit. Chin. Med. 2015, 49(7), 82-6.

5. Zhou, W.; Sun, W. B.; Zeng, Q. F.; Li, L.; Hao, X. Y.; Liang, Y. Pharmaceutical research progress on Toddalia asiatica. China J. Tradit. Chin. Med. Pharm. 2018, 33(8), 3515-22.

6. Zhang, X. Y.; Shang, H. C. Current situation and problems of clinical research on traditional chinese medicine in china in recent 10 years. J. Tradit. Chin. Med. 2018, 59(21), 1808-11.

7. Chen, X. X.; Simayi, R.; Long, S. J. Studies on chemical constituents of Toddalia asiatica stems. Northwest Pharm. J. 2013, 28(4), 337-9.

8. Cao, C.; Du, P.; Zhu, X.; Yan, H.; Song, X.; Zhu, H.; Geng, Y.; Wang, D. Rapid screening and purification of potential alkaloid neuraminidase inhibitors from Toddalia asiatica (Linn.) Lam. roots via ultrafiltration liquid chromatography combined with stepwise flow rate counter-current chromatography. J. Sep. Sci. 2019, 42(16), 2621-7.

9. Wei, M. C.; Liu, K.; Yi, Q.; Zhang, L. Y.; Zhou, H. H.; Dou, S. S.; Zhang, J. Analysis on fingerprint for root barks and stem barks of Toddalia asiatica. Chin. Tradit. Herbal Drugs 2016, 47(14), 2540-4.

10. Zhu, M. J.; Wei, P. Q.; Peng, Q.; Qin, S. Y.; Zhou, Y.; Zhang, R.; Zhu, C. C.; Zhang, L. Simultaneous qualitative and quantitative evaluation of Toddalia asiatica root by using HPLC-DAD and UPLC-QTOF-MS/MS. Phytochem. Anal. 2019, 30(2), 164-81.

11. Zhou, W.; Zeng, Q. F.; Luo, C. R.; Wan, L.; Zhang, X. Y. Analysis of chemical constituents of polar extract of toddalia asiatica root bark by LC-Q-TOF. China J. Tradit. Chin. Med. Pharm. 2019, 34(12), 5914-9.

12. Zhou, W.; Luo, C. R.; Liu, G.; Dong, W. Q.; Zhang, X. Y., Shen, X. C. GC-MS analysis of the root bark oil of toddalia asiatica. J. Guizhou Med. Univ. 2019, 44, 147-52.

13. Sun, W. B.; Yang, Z.; Liang, Y.; Li, L.; Hao, X. Y.; Zuo, G. Y.; Zhou, W. Chemical constituents from n-butanol part in Toddalia asiatica Root Bark. Chin. Pharm. J. 2018, 53, 1052-6.

14. Zhang, X. Y.; Sun, W. B.; Yang, Z.; Liang, Y.; Zhou, W.; Tang, L. Hemostatic chemical constituents from natural medicine Toddalia asiatica root bark by LC-ESI Q-TOF MS ${ }^{\mathrm{E}}$. Chem. Cent. J. 2017, 11, 55.

15. Zhao, M. X.; Zhang X.Y.; Liu S. H.; He, M. Q.; Liang, Y.; Hao, X. Y.; Zhou, W. Pharmacognostic identification and hemostatic activity of Toddalia asiatica root bark. Chin. J. Exp. Tradit. Med. Formulae 2016, 22, 32-6.

16. Zhou, W.; Xie, M. F.; Zhang, X. Y.; Liu, T. T.; Yu, Y. J.; Duan, G. L. Improved liquid chromatography fingerprint of fat-soluble Radix isatidis extract using multi-wavelength combination technique. J. Sep. Sci. 2011, 34, 1123-32.

17. Zhu, L. L.; Fang, L. X.; Li, Z. J.; Xie, X. M.; Zhang, L. A HPLC fingerprint study on Chaenomelis Fructus. BMC Chem. 2019, 13, 7.

18. Zhong, Y. C., Wang, H. Y.; Wei, Q. H.; Cao, R.; Zhang, H. L.; He, Y. Z.; Wang, L. Z. Combining DNA barcoding and HPLC fingerprints to trace species of an important traditional Chinese medicine fritillariae bulbus. Molecules 2019, 24, 3269. 
19. Duan, S. N.; Qi, W.; Zhang, S. W.; Huang, K. K.; Yuan, D. Simultaneous quantification combined with multivariate statistical analysis of multiple chemical markers of Wu Ji Bai Feng Pill by UHPLC-MS/MS. J. Food Drug Anal. 2019, 27, 1275-83.

20. Corleto, K. A.; Singh, J.; Jayaprakasha, G. K.; Patil, B. S. A sensitive HPLC-FLD method combined with multivariate analysis for the determination of amino acids in L-citrulline rich vegetables. J. Food Drug Anal. 2019, 27, 717-28.

21. Zhou, W.; Zhang, X. Y.; Lv, Y. P.; Liu, X. D.; Xu, C.; Duan, G. L. RSM-Optimized IRAE sample pretreatment and HPLC simultaneous determination of tryptanthrin, indigo, and indirubin from Chinese herbal medicine Radix Isatidis. Acta Chromatographica 2013, 25(2), 297-315. 